\title{
補繶/Prosthodonitjes
}

\section{今, なぜ Gysi 歯槽頂間線法則を問い直すのか？}

\section{加藤武彦}

\author{
Takehiko Kato
}

さまざまな歯科臨床においての患者満足度調査でいつも低位にあるのが総義歯臨床であ る。ましてや在宅往診においておや。なぜ！ 大学で教わったことが臨床で役に立ってい

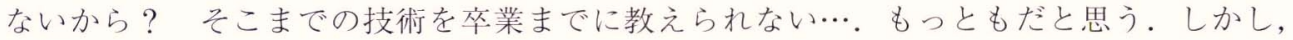
問題の一つに「現状にそぐわなくなった Gysi 料槽頂間線法則」があるのではないだろうか. 咬合のことを考える日本顎咬合学会であるからこそ，この問題を正面から取り上げてほ しい.

Key words : デンチャースペースに合わせた総義歯, 失われた骨を床で補う, 床の外形 は左右対称 (シンメトリー)，天然歯の元あったであろう位置に排列する

\section{はじめに}

8020 運動に表されているように，歯科界は自分の㐘で 噛めることがいかに全身の健康に役立つかということを 大々的にキャンペーンを行っている。 8020 ということが 歯科界として言えるようになったのは，カリエス，ペリ才 の予防法が確立し, 細かく定期検診により变失歯を少なく できる自信がついたからであろう。だが，現実問題として 現在の高齢者には，無歯顎患者が多い。この問題を歯科界 が歯科医療の対象としてしっかりと把握し，対策を練らな ければならない。自分の歯で噛むのでなけ机ば健康になれ ないというようなキャンペーンは, 歯科医療の敗北である。 歯を失った無歯顎患者でも，しっかりした義歯を装着し， よく咀嚼をすることにより，無歯旗患者でプロスキーヤー の三浦敬三さんのごとく，健康に長生きができるという キャンペーンも一方にあってしかるべきである。

神奈川県横浜市開業

\section{なぜ患者さんに満足いただける 義歯ができていないのか}

1. 技工のできない歯科医師と患者を診られない歯科技工 士とで...

国家試験に実技がなくなって以来，総義歯排列などは， 歯科技工士の仕事と思ったのか, 本当に手の動かない歯科 医師を多く見かける。筆者などは，ある時間内に総義歯の 排列を何度も練習することにより上下顎の間に立体的に人 工歯排列をするテクニックが植え付けられてきた経験か ら，歯科の技術習得には，できるようになって初めて理解 ができるのではないかという実感があるだけに，国家試験 に実技の再開を強く求めている.

技術が伴わないうちは，何が間違っているから，患者に 満足する義歯ができないのか, その解決の糸口すらつかめ ない。失われた骨を床で補うという義歯形態を診断し，印 象につなげるためには，歯科医師が技工をできなければ前 に進むことはできないと思われる。もう一度，「臨床実技 


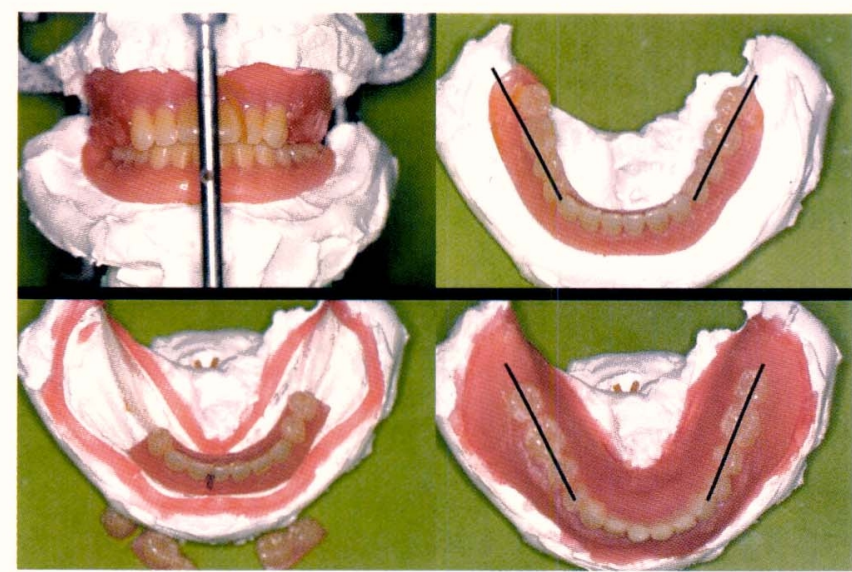

図 1 左上：新しい顎位で改造開始

右上：多く診る症例，小さくなった上顎に合わせて下顎人工歯を内 側に排列された症例。

左下：旧義歯の人工歯を利用しようと分解したところ

右下 : 結局, 前歯の排列位置まで変えざるを得ず, 新しい人工歯で の排列.

右上, 右下の黒線は, いわゆるパウンドライン
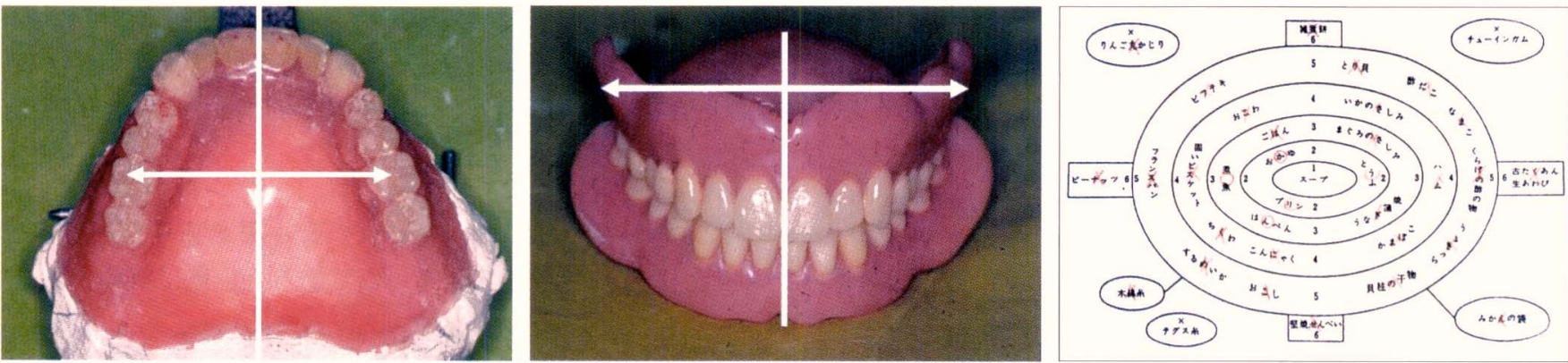

図2 左：床外形は左右対称。右：治療用義歯をトレーに作られた左右バランスのとれた完成 図 3 来院時, 山本式咀嚼能率判定表 義歯

の教育」を教育関係者に再考を促したいと思う。

このことが基礎にあって初めて，歯科技工士への指示が できる㐘科医師になれるのではないだろうか.

\section{2. 排列位置に関する教育の場での混乱}

排列位置に関する混乱は，いまだにGysi 歯槽頂間線法 則が国家試験の主流をなしているところに原因の一端があ ると思われる。過去 10 年の国家試験の問題傾向を見ると, 臼茵部の人工歯排列の出題は，ニュートラルゾーン，デン チャースペースの言葉の解釈は出てくるものの, 人工歯の 排列基準の基になる考えでこの問題を取り上げているわけ ではないので，教科書の上でも歯槽頂間線法則と二ュート ラルゾーンに人工歯を排列するということがなんの矛盾も なく，同等に語られている。ここに重大な䛊りがあると思 われる。総義歯作製実習に使うような優形な顎堤模型の場 合には，デンチャースペースと歯槽頂間線が一致する。し かし，今の高齢社会で遭遇する顎堤吸収の強い症例，言い 換えれば上顎は内側方向に吸収が起こり，下顎は平坦で外 側方向に吸収していった場合は，歯槽頂間線法則では上下 顎の歯列弓の差が大きくなった症例に対し，前歯部は審美 を考慮して天然歯の元あった位置に排列を許している。 方，臼㐘部は，歯槽頂間線と咬合平面のなす角が $80^{\circ}$ 以下
のものに関しては交叉咬合を推奨されている。しかし，そ の排列方法が本当に教育されたと损りに臨床が行われてい るならば，高齢社会の現在，当時よりも顎堤条件の悪く なった症例に対して巷にもっと交叉咬合の症例があってし かるべきだが，一般的には多く見ることはない.

\section{3.「てこの原理」}

小さくなった上顎歯列弓に対して，上顎の人工歯は歯槽 頂を基準にして排列し，それに合わせ下顎の人工歯を正常 咬合させるために排列位置を大幅に舌側にはみ出して排列 が行われている。このために，舌の生理的運動が阻害され る位置に排列されている症例を多く見る。この人工歯排列 の混乱は，いわゆる Gysiの「てこの原理」という理論に 則った「人工歯を歯槽頂より煩側に列べると安定が惠いが， 舌側ならば転覆力が働かず義歯の安定に働く」という原則 論も一つの災いの元になっているのではと思われる。きっ と，この排列を行っている歯科医師，㐘科技工士は，間 違った人工歯排列をしているとは意識していないであろ う。この原則は，周りの㚘筋や舌という義歯を維持安定さ せる周囲組織を一切考慮していない, 机上の静力学的な論 理という一面からのみのとらえ方だ思われる。 


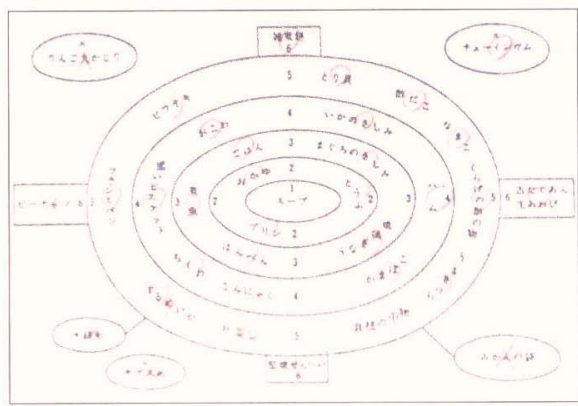

図4 完成時, 山本式咀嚼能率判定表.

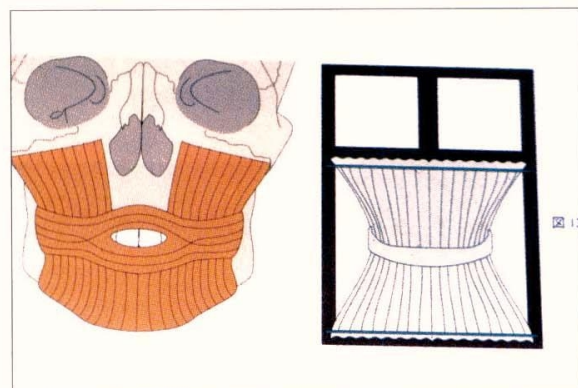

図7 㚘筋の緊張が義歯の維持, 安定に非常に

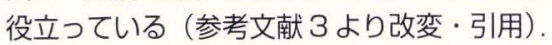

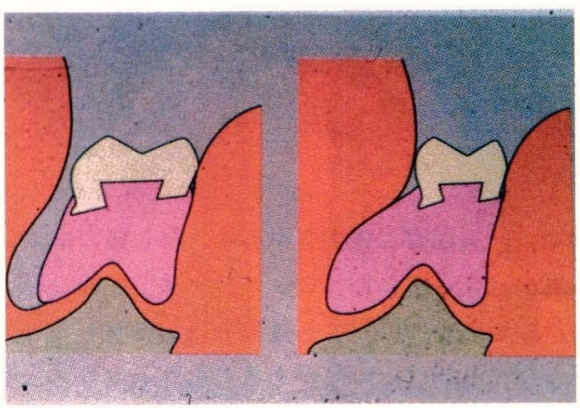

図 5 頬筋下方線維での抱き込みができる形態 が必要 (参考文献 3 より改変·引用).

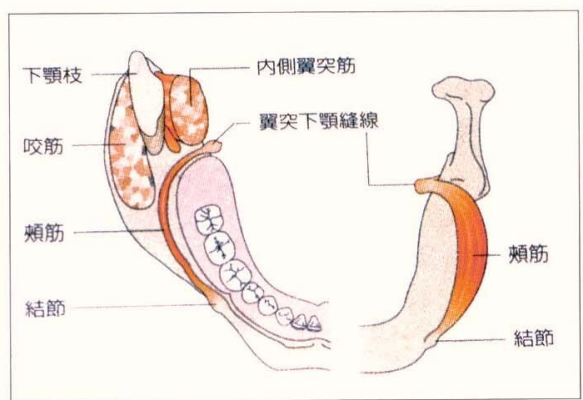

図 8 頪筋が下顎義歯の㚘側を抱き込める解剖 図 9 上顎の顎堤と床の厚みの状態. 学的理由 (参考文献7より改变·引用).

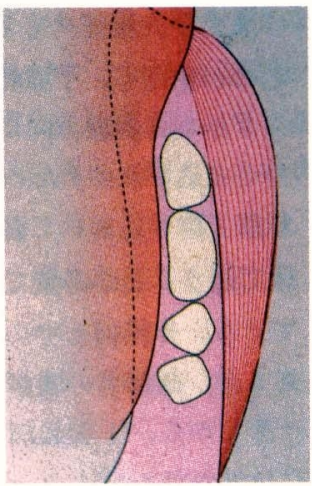

図 6 舌と㚘頁の筋圧 中立帯に作られた義 歯（参考文献 3 上 り改変. 引用).

\section{4. 歯科技工士の本音一採れていない印象}

臨床で多く見る義歯の辺縁形態は, ワックス 2 枚の厚み で均等に作られ，周囲組織との閉鎖弁を作る形態とは，ほ ど遠いものを多く見かける.

フラットな下顎の場合, よく咬合採得が決まらないと言 われるが，それ以前に骨体の印象が採れて辺縁封鎖ができ ないと下顎の吸着は得られない。そして, 上顎で歯槽頂を はずして人工㐘を排列しても，なお維持安定が保たれるた めには, 失われた骨を床で補い, ブッコ・リンガルサポー トが可能な床の厚みと深さが必要である。しかし，現実に はそこに見えている顎堤の印象を採るのが精一杯で, 技工 所に渡し，咬合採得が間違っていなければ，次の人工歯排 列での試適となる、筆者は，いろいろな歯科医師会での患 者実習を行っており，その時に歯科技工士から本音を聞く 機会があるが,「先生の言われることは理にかなっている が，現実に受け取る模型は周囲組織との閉鎖弁ができるよ うな厚い仮床を作れるようなものではない」と現実を叶露 される。

\section{筆者の総義歯に対する考え}

では，現実にどのように義歯を製作していくかを簡単に 述べる。
・デンチャースペースに合わせた総義歯

・失われた骨老床で補う

·床の外形は左右対称 (シンメトリー)

・天然㐘の元あったであろう位置に排列する

・吸着の得られた床で咀嚼を通して得られた中心位

・写真をお借りしてその人なりの個性を再現

\section{1. 下顎のフラットな顎堤に吸着を得る床を作るための印} 象

まず，下顎はフラット，これがあたりまえの時代になっ た。この顎堤で吸着を持たせられなければ咬合採得におけ る中心位は求められない。それには, 下顎義歯床の舌側辺 縁が一つのキーポイントになる。舌側の骨縁を含んだ骨面 をしっかり印象するためには，ABEトレーを用いてモデ リングーアルギン酸印象材のダブル印象を行い, シワのな い下頴骨面の印象を採得する。その印象面から完成義歯に なるべく近い仮床を作る。なぜ，このようなことに力を注 ぐかというと，この仮床を用いて咬合採得をする時に，吸 着が無ければ中心位を求められないことを知っているから である。そのためには, 本義歯で求めているような辺縁形 態が再現されないと吸着が求められないからである。レト ロモーラルパッドを $2 / 3$ ほど覆い, 外斜線を目安に外形を 


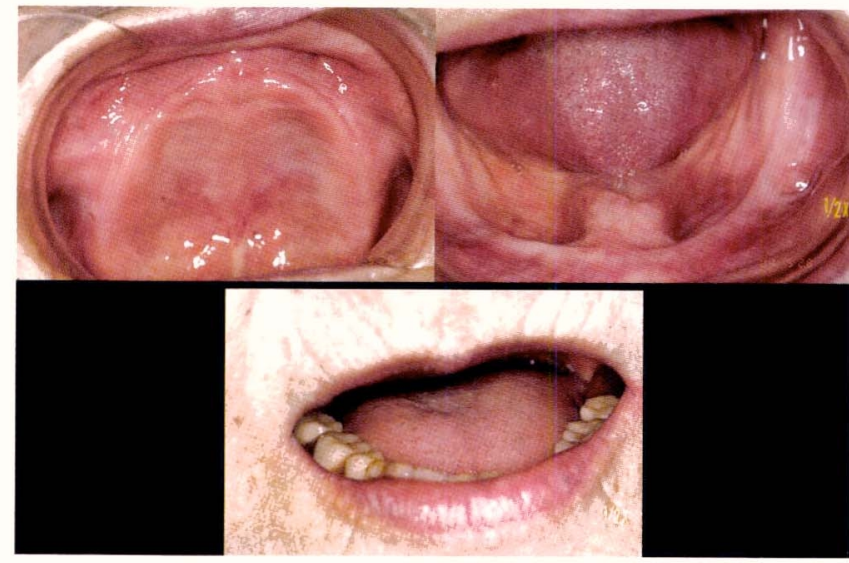

図 10 上：上顎，下顎ともに高度な顎堤吸収を見る。下：デン チャースペースに収まっている下顎義歯.

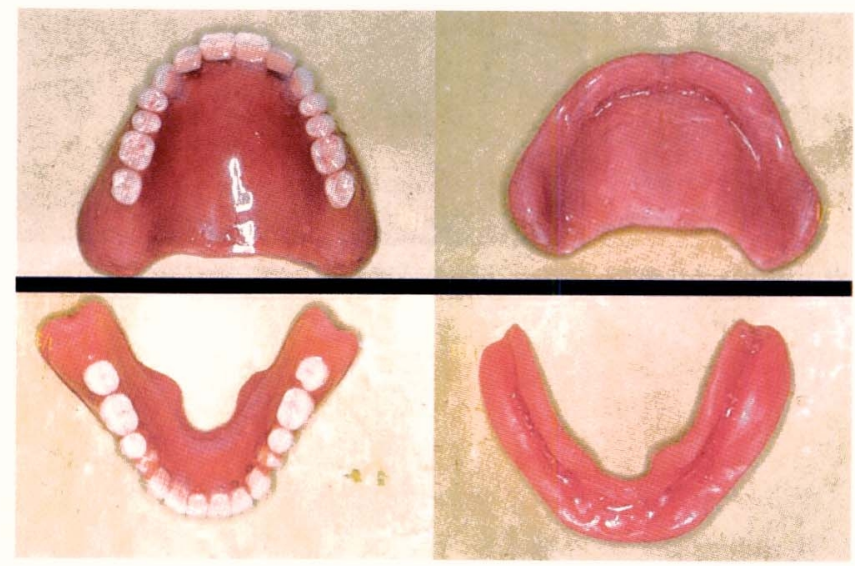

図 12 上下顎人工歯排列と粘膜面

決めるが，その場所の床の厚みは煩筋下方線維で抱き込ん で維持に役立てる厚みにする。そして, 頬小帯を避けた後, ある幅を持って前歯部に移るが，才トガイ筋の付着部が前 歯の側切歯の唇側に現れ，中央に下唇小帯の細い切れ込み が入る。舌側であるが，舌小帯を避けたところから舌側に ある幅を持って入るが，この部位は，顎舌骨筋によってで きる筋膜の上に閉鎖弁を作るために 2 〜 $\mathrm{mm}$ から 4 〜 $5 \mathrm{~mm}$ の幅を持たせる。この深さは, 燕下の時の緊張によ り義歯の浮き上がりとの関係において決まるので，それら の運動をさせながら深さと幅を決める。具体的にはフィッ トチェッカーを仮床全面に乗せた上で圓下をさせ，浮き上 がらないが吸着が得られる深さと幅を求める。 その幅と深 さは，第 1 大臼歯の舌側までいった後，今度は與荡下の時に 舌が床に強く圧せられるため, 後顎舌骨筋窩の床縁は薄く なる。このようにして仮床を製作すると吸着が得ら机るの で, 咬合採得時, 中心位の採得にはそれほど苦労しない。

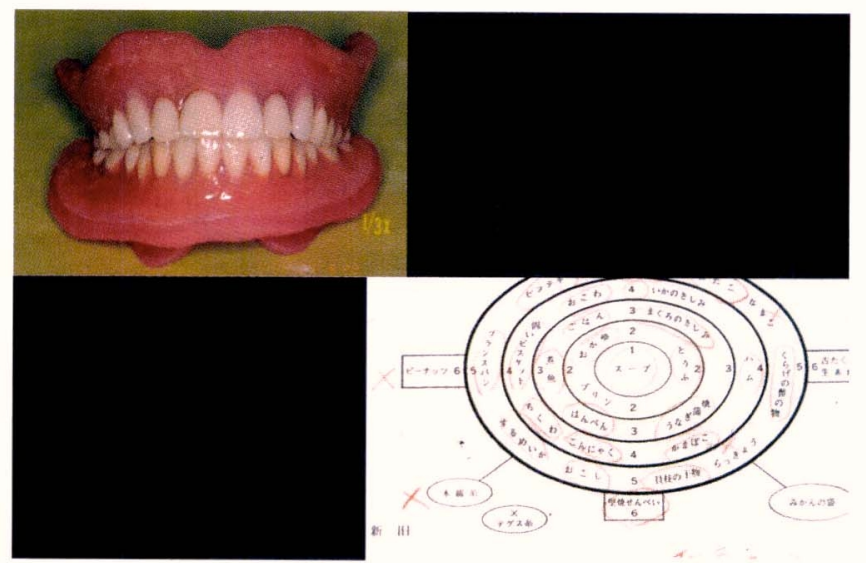

図 11 上：16年目で初めてシリコンの張り替えに来院された当日 の義歯. 下: 平成元年当時の咀嚼能率判定表 (現在も同様).

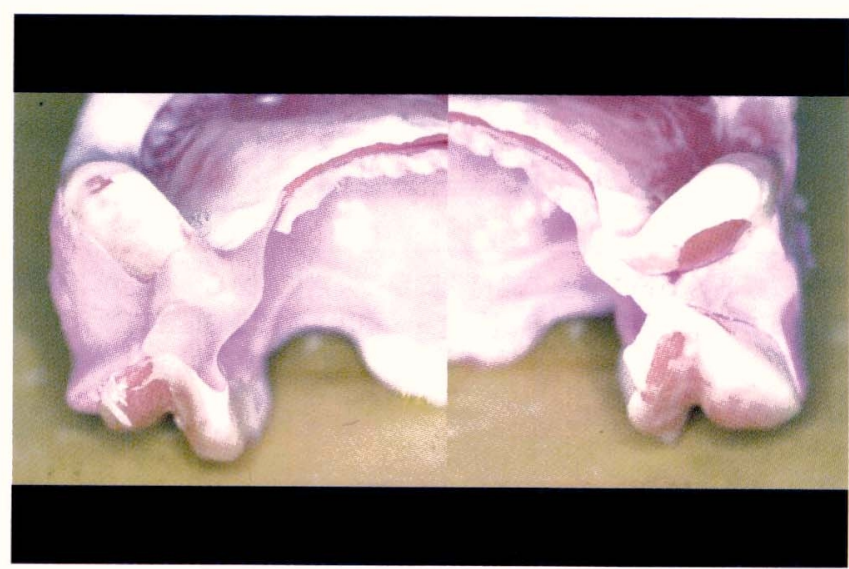

図 13 コピーデンチャーでの上下顎一塊印象

\section{2. 上顎は人工歯が正常排列できるような床の厚みが必要} 上顎の印象のキーポイントは，下顎のレトロモーラル パッドを基準に見て，どの程度，上顎骨の吸収があるかを 予測することが大切である。天然歯の元あったであろう位 置に人工歯を排列するためのべースになる床の厚みをここ

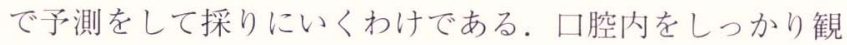
察し，その量を見きわめる。前歯部のフラビーなども，ま れなケースではない現在, 上顎の主な吸着を上顎結節部に おける床の辺縁形態を㚘筋上方線維で抱き込めるような形 態に作り，辺縁封鎖に求める。このようにして求めた義歯 の維持安定は, 歯槽頂から人工歯を外してもなお，咀嚼圧 に耐えうる義歯を製作するために，是非とも必要なわけで ある、通常、筆者は多少固めに練ったアルギン酸印象材の 単独印象で行うが, その時, 上顎結節の最後部㚘側に印象

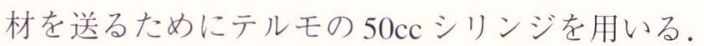




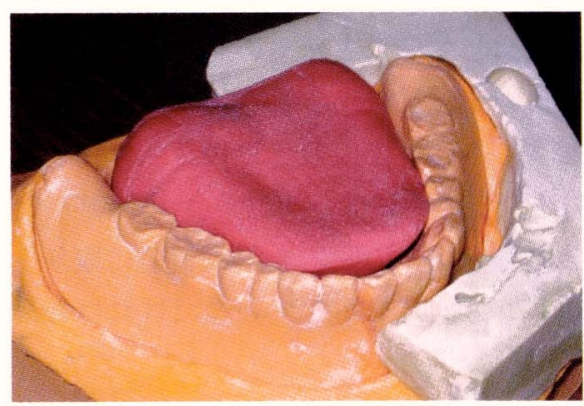

図 14 口腔内でどのように収まっているかを 図 15 上顎の顎堤と床の厚みの状態 チェック, 舌と自然態での㚘頁筋の状態.
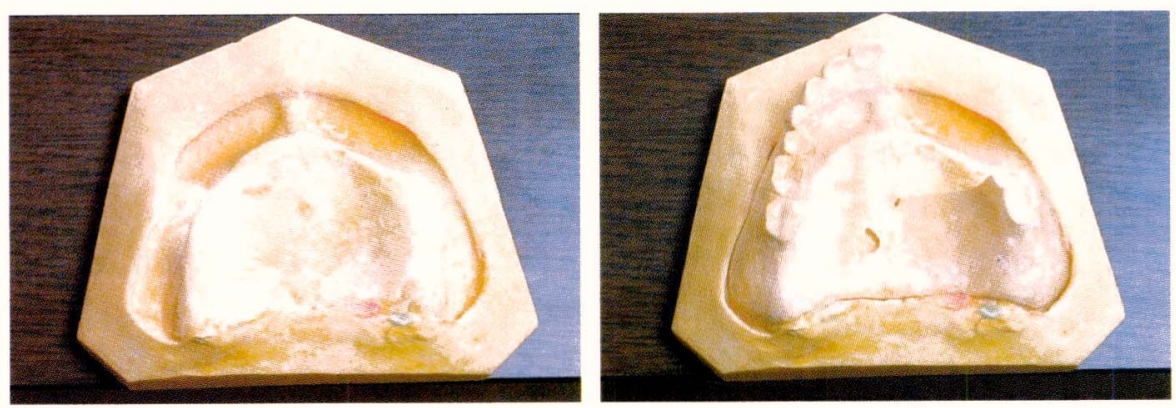

図 16 模型上に義歯を乗せると, このように 歯槽頂から外れている.

\section{3. 床の外形は左右対称}

仮床を作る段階に扔いて，左右の骨吸収は，抜歯された 原因が，カリエスによるものかペリオによるものかによっ て差が出てくるが, 仮床の外形は, ほほ左右対称になるの が正常である。これは, 人の顔のシンメトリーと関係し， よほどでないかぎり人の顔は, ほほ左右対称であるので, 失われた骨を補って㚘筋，口輪筋での閉鎖弁を求めるため に，ほほ左右対称に作製する。

上㖽の場合にも下䪽と同様，仮床の段階から本義㐘に似 せた形態を求める。上䫇結節を覆う床形態は，後方の翼突 下顎綘線からでる煩筋上方線維で義歯を上に抱き边めるよ うな形にする。これにはフィットチェッカーを何回も使い, 患者さんにこの義歯を抱き込んでくださいと指示すること により, 䫭筋上方線維の動きが印記されるので, 調整を 行って生理的運動をじゃましない形態を整える。次に煩骨 弓の部位は，多少幅広く切れ込みが行われた後，また元に 戻り㚘小帯の運動範囲を求めた後, 前歯部に移るが, 前歯 部の床は長すぎないことが重要である。また，この部位は 口腔周囲の審美への影響が非常に大きいので, ワックスフ レームを付けた状態での床の厚みを鼻唇溝が左右対称に出 るように，人中がはっきりと出るように調整する。このと きの条件として，その人の咬合高径が適正なものでなけれ ば床の厚みが審美形態を醸し出すことにはならない。咬合 高経が低いのに，床を厚くして口腔周囲の紴伸ばしをして いるケースがよくあるが，これは間違いである。また同時 に見るべきものは，上下の赤長の幅が同じかどうかである． このように，印象から本義歯の形態をこうあるべきと考え た仮床を用いて，咬合採得に移るわけである．

\section{4. 本来は天然歯のもとあった位置に排列すべし}

やはり，人丁歯は「天然歯の元あった位置」を求めて審 美, 咀嚼等, 生理的運動を阻害しない位置に排列すべきで
ある、そのため，昨今の患者の䫁堤条件に対応して人工㐘 を排列しようと思った時には, 歯槽頂間線法則だけでは対 応できない，筆者自身，2000 年の 4 月に脳梗塞を患い，片 麻痺を経験した時，頬を噛んだり，舌を噛んだり，多少の 䫇位のズレが，これほどまでに口腔内で障害をもたらすの か, という体験をした。であるから, 本来の位置から大き く外れた位置に排列された人工歯では, 患者はさぞ苦痛で あろうと思わざるをえない。

ニュートラルゾーンでの排列を実践するためには，上顎 臼歯部に执いて吸収された骨の量を床で補い, その煩粘膜, 口唇との閉鎖弁による吸着が，上㖽臼歯の排列位置を歯槽 頂から外しても維持, 安定に役立つという考えで行うため, 周囲の解剖，また，その組織の生理的運動範囲を，十分に 義㐘の形態に活かせないと, 上顎義歯は脱落するし, 咀嚼 に耐えることができない，

図 10 で示す症例は，上顎顎堤の吸収が著しく，しかも 前㐘部はフラビー。1 16 年前に製作した義歯だが，咀嚼は 図 11 で示すと扔りである。弾性裏装材のシリコンが剥が れたので, 張り替えにみえた。1 6 年前, 歯槽頂間線法則 を考えず，天然歯の元あったであろう位置に排列した症例 である、顎堤条件と人工歯の排列位置が，一枚の図の上で 表せないかと，いろいろ考えた末，このスーパーインポー ズ法で証明することができた。

\section{顎咬合学会のみなさんへのお願い}

今回，筆者は顎咬合学会 $(6$ 月) で，北九州市でご開業 の下川公一先生の座長の下,このタイトルで発表をさせて いただいた。また，近畿・中国・四国支部の認定教育研修 会 $(10$ 月) では, 德島大学解剖学の北村清一郎教授が 「総義㐘の印象採得に必要な局所解剖学の知識」と題して 講演をされたのとご一緒に, 私も歯槽頂間線の問題を発表 させていただいた。2002 年に総義歯の本の出版，2003 年 
にビデオ・DVD，そして今年は日本歯科医師会雑誌への 投稿と, 矢継ぎ早に総義歯臨床の混迷が何であるかを追求 してきた。また筆者は, 歯科在宅往診をライフワークとし ていたが，その目標として，「食べるところまでを診る」 と話してきた. そして今, 高齢社会で, 患者のニーズに対 応できていない総義歯臨床の元にあるものが，「歯槽頂間 線法則」ではないかと思うのである. 先進的な大学では,

\section{参考文献}

1）早川 巌：コンプリートデンチャーの理論と実際一総義歯 をイメージする一. クインテッセンス出版 (東京), 1995.

2）小林賢一：総義歯臨床の押さえどころ. 医歯薬出版 (東京), 2001.

3）Watt \& Mac Gregor 著; 小林義典, 田中 武, 鳥居健吾共 訳：コンプリートデンチャーの設計 1 st edition. 医歯薬出 版 (東京) 1979.

4） J. C. Hickey, G. A. Zard, C. L. Bolender 著; 田中久敏，松本直 之監訳：バウチャー 無歯顎患者の補緅治療. 医歯薬出版 (東京), 1988.
臨床おいて排列位置に関しては，天然歯の元あった位置を 基準に教えているが，国家試験に出るから歯槽頂間線法則 も覚えておけよと言う，本音と建前の教育がなされている とも聞く. 国家試験を直すためには, 補緅学会, その前に, われわれ顎咬合学会として，この問題を正式議題に取り上 げ，みなさんで討議して方向性を示していただければと思 い,この一文を記した。

5）加藤武彦：治療用義歯を応用した総義歯の臨床一いま総義 歯に求められるもの一. 医歯薬出版 (東京), 2002.

$$
D \vee D
$$

6）加藤武彦：治療用義歯を応用した総義歯臨床のテクニッ クーデンチャースペースに適合した総義歯の製作法一。株 式会社トクヤマデンタル, 2004.

7) 上條雍彦: 図説 口腔解剖学 2 筋学. アナトーム社 (東京), 1981. 